\title{
Henry Lefebvre's Rhythmanalysis as a Tool for Comprehensive Listening of the City
}

\author{
Adéla Procházková / adela.proch@gmail.com \\ Independent scholar, Prague, CZ
}

\begin{abstract}
In the 1980s French Marxist philosopher and sociologist Henri Lefebvre made an attempt to define a new science with practical consequences that would enable to gain a new form of knowledge, which he titled the rhythmanalysis. It is a theory which emphasizes a comprehensive perception of various aspects that shape the everyday experience of a man in modern city as well as conceptual method of multimodal and metaphorical listening. The rhythmanalysis involves cyclical (cosmic) and linear (mechanic) rhythms which are based on the spatiotemporal principles and the expenditure of energy within the subjects. The listening experience is then placed into the broader context of biologic, social and environmental conditions. The aim of the writing is to stress the necessity of a complex approach to the perception of the urban soundscape when the listener is aware of the great variety of aspects which form the acoustic ambiance of particular site.
\end{abstract}

\section{Keywords}

rhythm, rhythmanalysis, city, urban soundscape, listening, sound studies, architectural phenomenology, Henri Lefebvre, Juhani Pallasmaa, Steen Eiler Rasmussen, Gaston Bachelard 
"Rhythmanalyst is always 'listening out', but he does not only hear words, discourses, noises and sounds; he is capable to listen to a house, a street, a town, as one listens to a symphony, an opera. Of course, he seeks to know how this music is composed, who plays it and for whom."

Henri Lefebvre

A city is a framework for countless sonic events of different origin which are nevertheless dominated by a man and his activity. Since the beginning of Industrial Revolution in the 18th century, a soundscape of the city has been considered a noisy outcome of the hectic and mechanized life of its inhabitants. However, even the busy city can experience quiet moments which appear during specific day times or seasons depending on the rhythm of its inhabitants and other factors. How is it then possible to define the specific soundscape of a particular site when the sonic events are ceaselessly changeable and unrepeatable? What aspects and relations should the listener be aware of and which method could be opt for perceiving the urban soundscape in its entirety?

Sound mapping, the prevailing practise of sound studies, is being discussed as too selective, individualized and exclusive of many relational aspects. ${ }^{2}$ As R. Murray Schafer states "to give a totally convincing image of a soundscape would involve extraordinary skill and patience: thousands of recordings would have to be made; tens of thousands of measurements would have to be taken; and a new means of description would have to be devised." Barry Truax points out that sound libraries and sound mapping projects can potentially create more distanced relationship to the captured sound material because "one is tempted to treat them as 'text', not 'context'." "He particularly emphasizes soundwalking as the ideal most direct experience of the soundscape which enables phenomenological approach to the perceived ambiance and is repeatable during different times of a day for more complex experience. The method they both call for clearly requires more than a strict listening approach and is related to spatiotemporal dimension of the sonic environment and broader understanding of its context.

The similar requirements on the perception of the urban sonic ambiance were included in the concept of the rhythmanaylsis of French Marxist philosopher and sociologist Henri Lefebvre in his 1980s essays The Rhythmanalytical Project and Attempt at the Rhythmanalysis of Mediterranean Cities and his 1992 book Elements of Rhythmanalysis. Lefebvre

1 LEFEBVRE, Henri. Rhythmanalysis: Space, Time and Everyday Life. London: Continuum, 2004, p. 1.

2 For instance Jacqueline Waldock discusses beside other things a gender aspect of sound mapping, private and public issues and questions of access to the data in her essay Soundmapping: Critiques And Reflections On This New Publicly Engaging Medium [URL: http://journal.sonicstudies.org/vol01/nr01/a08, accessed 2. 9. 2017]. Several essays of the publication The Acoustic City respond to the problematics including Gascia Ouzounian's writing Acoustic Mapping: Notes from the Interface with several observations of Steph Ceraso and her critique of visual aspects of sound maps [GANDY, Matthew, BJ Nilsen (Eds.). The Acoustic City. Berlin: Jovis, 2014].

3 SCHAFER, R. Murray. The Soundscape: Our Sonic Environment and the Tuning of the World. Rochester, Vermont: Destiny Books, 1994, p. 8.

4 TRUAX, Barry. Sound, Listening and Place: The Aesthetic Dilemma.[online]. [Cit. 2. 9. 2017]. URL: http:// www.sfu.ca/ ${ }^{\sim}$ truax/OS8.html. 
intends to "find a science, a new filed of knowldege [savoir]: the analysis of rhythms; with practical consequences, " where rhythm is defined as time-space-energy triadic not merely referring to a sound. He acknowledges the rhythm to most aspects of everyday life in modern society including urban structures, economical causalities or biological processes of living matters. Lefebvre's rhythmanalysis is highly unique in terms of defining both theory and method applicable in practise and for its concept of multimodal listening. The aim of this writing is to emphasise on the concept of the rhythmanalysis the necessity of a comprehensive approach to the perception of the urban soundscape when the listener is aware of the great variety of aspects which form the acoustic ambiance of particular site. Therefore, the rhythmanalysis will be observed from the perspective of sound studies as well as phenomenology of architecture, philosophy and others.

\section{Lefebvre's Definition of Rhythm}

According to The Hutchinson Concise Dictionary of Music, the rhythm is "the way that sounds of varying length and stress (or accent) are grouped together in patterns. " Lefebvre himself draws from the music theory in the definition of rhythm but simultaneously accentuates the rhythm as quite unexplored phenomenon even for music. ${ }^{7}$ For Lefebvre "everywhere where there is interaction between a place, a time and an expenditure of energy, there is rhythm." With time, space and energy elements of the rhythm he paraphrases the key components of music - melody, harmony, rhythm - and argues the music is also a temporal phenomenon which is being formed by spatial conditions.

Lefebvre observes the rhythm has been connected mainly with sacred music and its manifestations in form of rites which place the emphasis on the concept of a body and dance. In Lefebvre's concept of rhythm and rhythmanalysis the body plays a key role. Consisting of many different rhythms including breathing, heartbeat, rhythms of brain, senses and intellect, social rhythms like sleep, work and rest, the body is "the paradigm of rhythmological study. " In terms of the rhythmanalysis, body should serve the rhythmanalyst as a primal source of knowledge. As Lefebvre describes, "he listens - and first to his body; he learns rhythm from it, in order consequently to appreciate external rhythms. His body serves him as a metronome." 10 Juhani Pallasmaa notes from the point of architectural phenomenology the body is always bounded with its surroundings and the personal experience of the city is shaped by the bodily experience of the urban structure and its scales, distances and proportions. He stresses these two entities define each other and

5 LEFEBVRE, op. cit., p. 3.

6 Rhythm [heslo]. The Hutchinson Concise Dictionary of Music. Abingdon, Oxon: Helicon Pub., 2006, p. 1851.

7 LEFEBVRE, op. cit., p. 57.

8 Ibid., p. 15.

9 Ibid., p. 68.

10 Ibid, p. 19. 
concludes "I dwell in the city and the city dwells in me." ${ }^{11}$ All conceivable measures are being compared to the ones known by the body which is our primordial source of comparison.

Several types of rhythms originally related to the body but applicable in broader sense were also defined by Lefebvre: Isorhythmia, the equality of rhythms which coincide, polyrhythmia, composed of diverse rhythms, eurhythmia, the harmony of different rhythms, and arrhythmia, disruption of rhythms, the pathological state. ${ }^{12}$ Lefebvre describes polyrhythmia and eurhythmia as healthy states of the body or other units like trees, flowers, birds and insects which are supposed to "form polyrhythmia with the surroundings." 13 Nevertheless, we are not usually aware of the regular rhythms and stability and we pay attention only to the irregularities of the rhythm, which inform us on the imbalances and diseases of the system.

One of the principal attributes of the rhythm is its temporal dimension. According to Lefebvre, rhythm is a repetition in time and space which is never absolute and produces differences. ${ }^{14} \mathrm{He}$ distinguishes two types of rhythms according to their origin: cyclical and linear. Cyclical rhythms are symptomatic for cosmos and nature. They appear in large and simple intervals and are perceived rather favourably. It is the rhythm of the days and nights, seasons, waves or biological rhythms. Linear rhythms are connected with human activity, they tend to be monotonous and tiring and often related to mechanical work. Lefebvre speaks about dialectical relation of these two types of rhythms since "everything is cyclical repetition through linear repetitions." 15

Lefebvre's rhythmanalysis also involves the rhythms of the capitalist society itself. In case of rhythms present in social and economic spheres it is possible to talk about cycles, periods, eras and rhythms of production, consumption and circulation. ${ }^{16} \mathrm{He}$ also defines a rhythm of an era which is a characteristic phenomenon of particular meaning produced by a group in specific time. ${ }^{17}$ Steen Eiler Rasmussen endorses this statement when claiming that "people who live in the same country at the same time often have the same sense of rhythm. They move in the same way, they receive pleasure from the same experiences." 18 The rhythm of an era is dependent on the paragons of the epoch which are variable in time. As Rasmussen states new rhythms govern almost every sphere of modern life including architecture, film, sport and body. Architecture of different periods could be then understood as a manifestation of varying rhythms.

11 PALLASMAA, Juhani. The Eyes of the Skin: Architecture and the Senses. Chichester: John Wiley \& Sons Ltd, 2005, p. 40.

12 LEFEBVRE, op. cit., pp. 67-68.

13 Ibid., p. 17.

14 Ibid, pp. 6-7.

15 Ibid, p. 8.

16 Ibid, p. 6, 73.

17 Ibid, p. 14.

18 RASMUSSEN, Steen Elier. Experiencing Architecture. Cambridge: The M.I.T. Press, 1964, p. 135. 


\section{The Rhythmanalysis and The Rhythmanalyst}

The term rhythmanalysis originates with Portugese philosopher Lúcio Alberto Pinheiro dos Santos who focused on the theory of rhythm from the perspective of modern wave physics, medical science and psychology. His 1931 book Rhythmanalysis influenced Gaston Bachelard who had a great impact on the theory of Henry Lefebvre. Bachelard's view of the rhythmanalysis was published in The Dialectic of Duration at 1936 in which he defines rhythm as dialectical phenomenon apparent in many aspects of life. He supposes the "rhythmanalysis will look anywhere and everywhere in order to discover new opportunities for creating rhythm." ${ }^{19}$ Bachelard exceeds the scientific approach of dos Santos and regards rhythm in more metaphorical way with a help of musical expressions for describing the rhythm and the relation of its elements. He also attributes rhythm to urban structures when stating that "our houses are built with an anarchy of vibrations. We walk on the anarchy of vibrations. We sit down on the anarchy of vibrations." 20

Lefebvre follows up Bachelard's theory of rhythm and introduces the concept of the rhythmanalysis as a method suitable for an observation of many different aspects of everyday life in modern urban society. He criticises the dominance of vision and superficiality of spectacles and accentuates other senses, especially hearing and the ability to listen. For Lefebvre, listening is very complex matter which does not exclude other senses but on the contrary embrace them into the experience. In the chapter Seen from the window of this book Elements of Rhythmanalysis Lefebvre describes the acoustic ambiance of his surroundings experienced from his apartment window. At first his observations seem relatively similar to the soundwalker's ones since he listens to the surroundings, especially noises, murmurs and silence..$^{21}$ This attentive type of listening has been outlined by Pierre Schaeffer in 1950s and followed by many musicians, sound theorists and philosophers. ${ }^{22}$ Schaeffer introduced a concept of ordinary listening, especially the listening mode called entendre which supposes the listener to perceive the sound without the focus on its origins or the source. The sound is perceived only for its acoustic qualities as the sound object (l'objet sonore). ${ }^{23}$ But when Lefebvre listens to the rhythms of pedestrians, schoolchildren or traffic, he is aware of the cyclical character of those rhythms which intensity changes during the day in relation to the mechanisms of the social and economic order. In the essay The Rhythmanalysis of Mediterranean Cities he links the rhythm of Mediterranean sites with the rhythmical heaving of waves, commercial relations of the ports, arrhythmia caused by pirates and naval wars or political constitution based on

19 BACHELARD, Gaston. The Dialectic of Duration. Manchester: Clinamen Press, 2000, p. 151.

20 Ibid., p. 137.

21 LEFEBVRE, op. cit., p. 19.

22 Including Pauline Oliveros, Barry Truax, R. Murray Schafer, Roland Barthes, Pascal Amphoux, Jean-Francois Augoyard, Henry Torgue and others.

23 SCHAEFFER, Pierre. Traité des objects musicaux. Paris: Édition dans Seuil, 1966, pp. 107-111. 
polyrhythmic compromises. ${ }^{24}$ The rhythm of the site is therefore constituted by far more complex phenomena than of those which are directly sensible and realizable.

The rhythmanalysis as a new science and form of knowledge thus exceeds the concept of listening to the sounds as a physical phenomenon. Lefebvre incorporates also the subjects which do not produce any obvious sound to the listening experience. He supposes the rhythmanalyst to be capable of deeper observations of processes happening beneath a surface. The author claims every object or living entity is made up of several rhythms which might not be perceptible at first because they are too slow in comparison to our time and human body rhythms. These hidden occurrences are strictly temporal since every substance has a frequency caused by the expenditure of energy which relates to the physical principles of sound and listening. With this on mind, one "will grasp every being [chaque être], every entity [étant] and every body, both living and non-living, -'symphonically' or 'polyrhythmically'. You will grasp it in its space-time, in its place and its approximate becoming: including houses and buildings, towns and landscapes. ${ }^{25}$ The rhythmanalyst should be able to understand the rhythms of the objects like a stone or wall and become aware of their time. As Lefebvre mentions, "to the attentive ear, it makes a noise like a seashell." 26

The role of the body and mind in receiving the rhythm is also stressed by Rasmussen who claims the architecture can't be rhythmic in the same manner as music or dance because it does not contain motion and temporal dimension but it is the experience of architecture which requires time and mental effort: "The person who hears music or watches dancing does none of the physical work himself but in perceiving the performance he experiences the rhythm as though it were in his own body. In much the same way you can experience architecture rhythmically - that is, by the process of recreation already described." ${ }^{27}$ Lefebvre himself observes the rhythmic qualities of architecture particularly in public staircases which rhythms the walk in the urban environment and creates the link between spaces as well as between times. ${ }^{28}$ Pallasmaa similarly states every deeper experience of architecture is multisensory, equally perceived by sight, listening, smell, tactile experience and our motion apparatus which closely interact and fuse into each other. ${ }^{29}$

According to Pallasmaa the most important aural experience of the architecture is its calmness: "Ultimately, architecture is the art of petrified silence." ${ }^{30}$ Historical buildings are witnesses of the past and the silence allows us to experience the history, the healing flow of the time. ${ }^{31}$ Just as the rhythmanalysis Pallasmaa accentuates the temporal standpoint of urban milieu. According to Lefebvre the rhythmanalyst is more interested in temporal than spatial qualities and to the atmosphere rather than events and spectacles. As a re-

24 LEFEBVRE, op. cit., pp. 91-93.

25 Ibid., p. 80.

26 Ibid., p. 20.

27 RASMUSSEN, op. cit., p. 135.

28 LEFEBVRE, op. cit., p. 97.

29 PALLASMAA, op. cit., p. 41.

30 Ibid., p. 51.

$31 \quad$ Ibid., p. 52. 
sult, one "thus knows how to listen to a square, a market, an avenue." 32 The rhythmanalyst is capable to listen to the city in its totality, appreciate the rhythmic aspects of urban structures and understand the ambiance is formed not only by the transient human activity but also by the persistent conditions which form the everyday experience.

\section{Conclusion}

When composing Music in Twelve Parts in the 1970s, Philip Glass used to make a living as a taxi driver. Radio host John Schaefer finds parallels of this repetitive minimalist composition and an experience of someone who is driving a car through the streets of New York, which seem endless and almost identical at the first time but a sudden change of the direction to the boulevard can bring completely different texture to the experience..$^{33}$ Glass himself states that "the pulse of the music is a part of the life of America" 34 and compares this pulse to the intensity of excitement which was then present in the atmosphere of New York.

The rhythmanalysis is a comprehensive theory and conceptual method which requires from the rhythmanalyst the attentive and creative observation of all conceivable aspects related to his surroundings. He should become aware of their temporal qualities and perceive them by multimodal listening. It is the concept of metaphorical listening which brings to the rhythmanalysis an artistic approach. Lefebvre even claims the rhythmanalyst "seems close to the poet, or man of the theatre." 35

Even though the rhythmanalysis might be too abstract as a tool of theoretical observation of the urban soundscape and too conceptual as a listening method, it is the idea of the experience simultaneously being shaped by various biological, environmental, urban and social aspects which should be considered when discussing the urban soundscape. The way the city is being constructed have an impact on how it will be used, moved through and lived and it will shape its acoustic ambiance. The listener should then perceive the sound of the site with an awareness of the complex relations.

\section{Bibliography}

BACHELARD, Gaston. The Dialectic of Duration. Manchester: Clinamen Press, 2000.

LEFEBVRE, Henri. Rhythmanalysis: Space, Time and Everyday Life. London: Continuum, 2004.

32 LEFEBVRE, op. cit., p. 89.

33 SCHAEFER, John (Presenter) and SMITH, Paul (Producer). Philip Glass: Taxi Driver [audio podcast]. London: Just Radio, 2015. [Cit. 4. 9. 2017]. URL: http://www.bbc.co.uk/programmes/b065tqz1.

34 Ibid.

35 LEFEBVRE, op. cit., p. 25. 
PALLASMAA, Juhani. The Eyes of the Skin: Architecture and the Senses. Chichester: John Wiley \& Sons Ltd, 2005.

RASMUSSEN, Steen Elier. Experiencing Architecture. Cambridge: The M.I.T. Press, 1964.

Rhythm [heslo]. The Hutchinson Concise Dictionary of Music. Abingdon, Oxon : Helicon Pub., 2006.

SCHAEFER, John (Presenter) and SMITH, Paul (Producer). Philip Glass: Taxi Driver [audio podcast]. London: Just Radio, 2015. [Cit. 4. 9. 2017]. URL: http://www.bbc.co.uk/programmes/ b065tqz1.

SCHAEFFER, Pierre. Traité des objects musicaux. Paris: Édition dans Seuil, 1966.

SCHAFER, R. Murray. The Soundscape: Our Sonic Environment and the Tuning of the World. Rochester, Vermont: Destiny Books, 1994.

TRUAX, Barry. Sound, Listening and Place: The Aesthetic Dilemma.[online]. [Cit. 2. 9. 2017]. URL: http://www.sfu.ca/ truax/OS8.html. 